\title{
Review
}

\section{Thyroid hormones and retinoids: A possible link between genes and environment in schizophrenia}

\author{
Joana Almeida Palha ${ }^{a, *}$, Ann B. Goodman ${ }^{b}$ \\ ${ }^{a}$ Life and Health Sciences Research Institute (ICVS), School of Health Sciences, University of Minho, Campus Gualtar, 4710-057 Braga, Portugal \\ ${ }^{b}$ The Massachusetts Mental Health Center Academic Division of Public Psychiatry in the Department of Psychiatry at Beth Israel Deaconess \\ Medical Center, Harvard Medical School, Boston, MA 02115, USA
}

\section{A R T I C L E I N F O}

Article history:

Accepted 3 October 2005

Theme:

Neurotransmitters, modulators, transporters and receptors

Topic:

Signal transduction: gene expression

Keywords:

CYP26

Myelination

Thyroid hormone

Trace amine associated receptor Retinoic acid

Retinaldehyde dehydrogenase

Abbreviations:

$\mathrm{ADH}$, alcohol dehydrogenase

ALDH, retinaldehyde dehydrogenase

\begin{abstract}
A B S T R A C T
Phenotypic discordance for schizophrenia in monozygotic twins clearly indicates involvement of environmental factors as key determinants in disease development. Positive findings from genome scans, linkage and association studies apply in only a minority of those affected, while post-mortem brain investigations reveal altered expression of genes and proteins involved in numerous neurodevelopmental, metabolic and neurotransmitter pathways. Such altered expressions could result, on the one hand, from mutations in coding regions or polymorphisms in the promoter and regulatory regions in genes within those areas identified by gene searches or, on the other hand, from inadequate amounts of modulators, transporters and synthesizers of transcription factors necessary for regulation of the putative genes. Hormones and vitamins are such modulators. They could serve as bridges between genes and environment in schizophrenia. Multiple evidence supports the suggestion of retinoids and thyroid hormones as plausible actors in these roles. Both are not only essential for normal development of the central nervous system but also regulate the expression of many neurotransmitters, their synthesizing enzymes and receptors, and other genes in broader signaling transduction cascades affecting pathways that are altered in response to treatment. Functional and positional candidate genes include retinoic acid and thyroid hormone receptors, retinaldehyde dehydrogenases and deiodinases, which synthesize the powerful morphogens, retinoic acid and triiodothyronine, and the enzymes involved in their inactivation. This review highlights selective evidence supporting the retinoid and thyroid hormone hypotheses of schizophrenia.
\end{abstract}

(ㄷ 2005 Elsevier B.V. All rights reserved.

\footnotetext{
* Corresponding author. Fax: +351 253604809.

E-mail address: japalha@ecsaude.uminho.pt (J.A. Palha).
} 
CRABP, cellular retinoic-acidbinding protein

CRBP, cellular retinol-binding protein

CSF, cerebrospinal fluid

CYP, cytochrome P450

LRAT, lecithin-retinol

acyltransferase

PPAR, peroxisome-proliferator-

activated receptor

$R A$, retinoic acid

RAR, retinoic acid receptor

$\mathrm{RBP}$, retinol-binding protein

$\mathrm{RDH}$, retinol dehydrogenase

$\mathrm{REH}$, retinyl ester hydrolase

$\mathrm{RXR}$, retinoid $\mathrm{X}$ receptor

$\mathrm{T}_{3}$, triiodothyronine

$\mathrm{T}_{4}$, thyroxine

TAAR, trace-amine-associated

receptor

TBG, thyroxine-binding globulin

THR, thyroid hormone receptor

TSH, thyroid-stimulating hormone

TTR, transthyretin

\section{Contents}

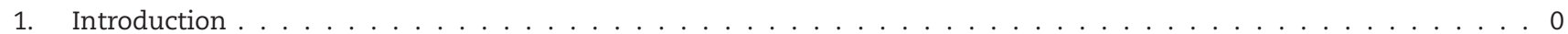

2. Thyroid hormone and vitamin A metabolism and mode of action . . . . . . . . . . . . . . . . . . . . . . 0

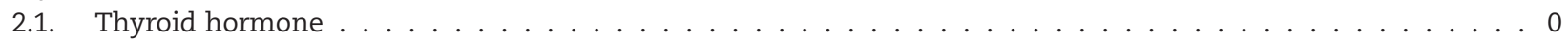

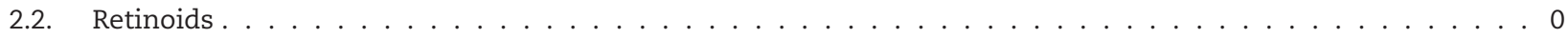

3. Thyroid hormones, retinoids and schizophrenia . . . . . . . . . . . . . . . . . . . . . . . 0

3.1. Chromosomal loci for schizophrenia . . . . . . . . . . . . . . . . . . . . . . . 0

4. Schizophrenia candidate genes regulated by retinoic acid and thyroid hormones . . . . . . . . . . . . . . . . . . . 0

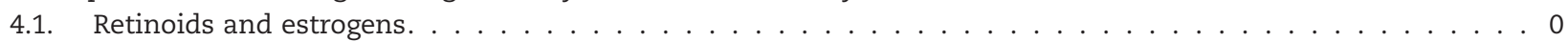

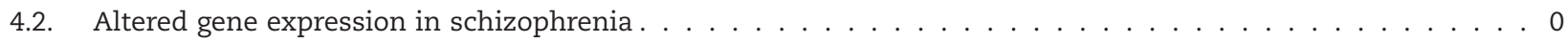

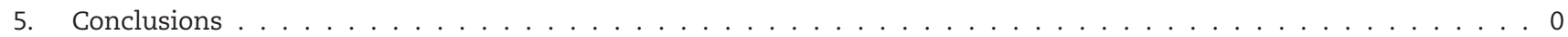

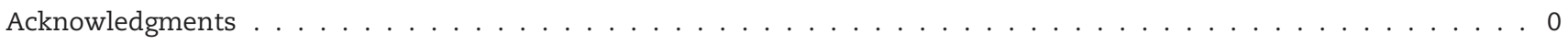

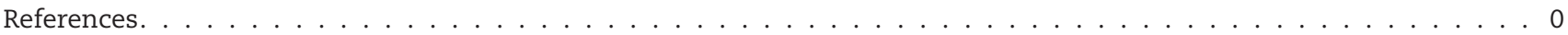

\section{Introduction}

While there is strong evidence supporting genetic causation in schizophrenia, epigenetic and environmental factors are also believed to play a major role in the disease onset (Goodman, 1998; Mackay-Sim et al., 2004; Owen et al., 2004; Ozer et al., 2004; Sharma, 2005; Suzuki et al., 2004; Tsuang et al., 2001). Recently, some success has been achieved in identifying significant involvement of single genes across several different ethnic or population groups but in no instance has there been total replication of such involvement across all groups studied. The disease is thought to be initially characterized by diverse neurodevelopmental insults occurring in the later half of gestation, with the subsequent combination of both genetic vulnerabilities and environmental stressors resulting in the usual age of onset in mid-to- late adolescence. Based on response to treatment, various neurotransmitter cascades have been implicated in the etiology of schizophrenia, with special emphasis on the dopaminergic hypothesis in which schizophrenia results from increased dopaminergic stimulation in the limbic system.

In view of the lack of wide replicability of genome-wide scans and inconclusive results from association studies of missense and nonsense mutations such as those responsible for simple genetic disorders, the approach to study this complex disease has broadened to include investigations and functional analyses of human promoter polymorphisms. There are hopes that such approaches will prove productive for recent studies have shown a large proportion of genes with polymorphic promoters (Buckland et al., 2004; Hoogendoorn et al., 2003; Perkins et al., 2005) responsible for altered gene expression. It is possible that, 
rather than being caused by mutated genes alone, schizophrenia results from the altered expression of normal genes (Goodman, 1996a). In addition to discrete mutations in coding regions, altered expression of candidate genes could result either from polymorphisms in the promoter and regulatory regions of the genes or from inadequate supply of modulators of transcription factors activity (Nobel et al., 2001).

Transcriptional factors and their ligands (such as hormones and vitamins) are promising candidates in the link between the genetic and environmental components of complex diseases such as schizophrenia. The genetic cascades which make ligands available to activate nuclear transcription factors at specific times in development and at specific cellular locations are complex. Normal allelic variants in any of the metabolic enzymes of the cascade or of the ligand transporters could combine to alter ligand availability.

\section{Thyroid hormone and vitamin A metabolism and mode of action}

Fig. 1 summarizes major pathways of thyroid hormone and vitamin A metabolism and their interaction at the level of gene transcription regulation. Roles in schizophrenia of thyroid hormone and vitamin A have been proposed, and evidence supporting this hypothesis has been summarized (Goodman, 1998). The purpose of this article is to update the hypothesis with new data that have appeared in the literature, most of them post-2003. These new data aid in the interpretation of the already existing hypothesis.

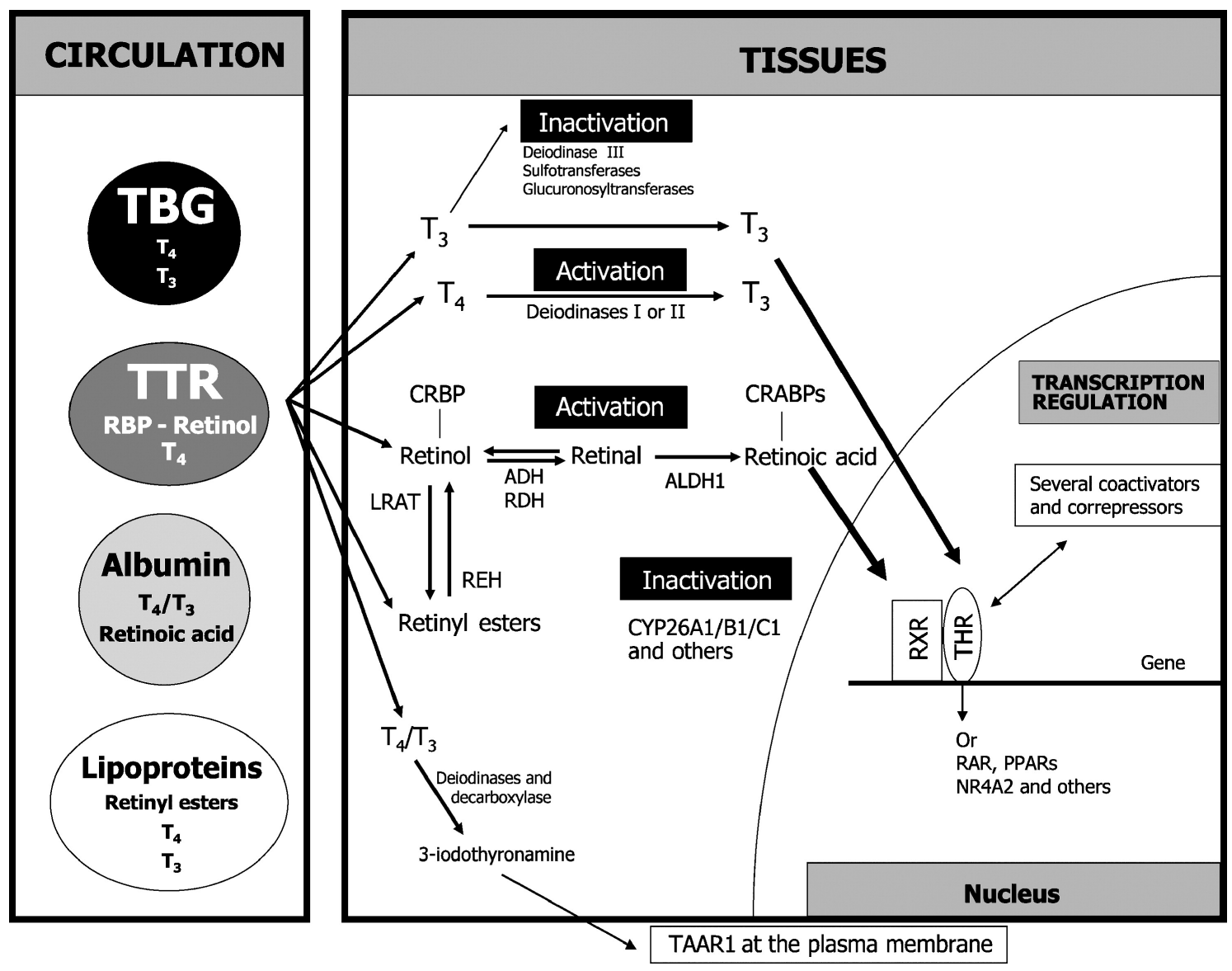

Fig. 1 - Overview of thyroid hormone and retinoid transport, metabolism and mechanisms of action. Thyroid hormone and retinoid in circulation enter the cells and are converted into their active forms or inactivated by specific metabolic pathways. The activated hormone/vitamin that enters the nucleus, upon binding to nuclear receptors, influences gene expression. Thyroid hormone and retinoids also target cell membrane receptors, as exemplified by the interaction of 3-iodothyronamine with TAAR1, and intracellular signaling transduction pathways. ADH, alcohol dehydrogenase; CRABP, cellular retinoic acid binding protein; CRBP, cellular retinol-binding protein; CYP, cytochrome P450; LRAT, lecithin-retinol acyltransferase; PPAR, peroxisome-proliferator-activated receptor; ALDH1, retinaldehyde dehydrogenase; RAR, retinoic acid receptor; RBP, retinolbinding protein; $R E H$, retinyl ester hydrolase; $R D H$, retinol dehydrogenase; $R X R$, retinoid $X$ receptor; $T_{3}$, triiodothyronine; $T_{4}$, thyroxine; TAAR, trace-amine-associated receptor; TBG, thyroxine-binding globulin; THR, thyroid hormone receptor; TTR, transthyretin. 


\subsection{Thyroid hormone}

Thyroid hormones are essential for cellular metabolism, growth and differentiation of several organs including the brain (Bernal, 2002; Yen, 2001). Synthesis of thyroxine $\left(T_{4}\right)$, the major product secreted by the thyroid gland, requires the active uptake of dietary iodine by the gland. Regulation of thyroid hormone secretion is tightly regulated by the pituitary thyroid-stimulating hormone (TSH) (gene acronyms/abbreviations and gene names are specified in accordance with the HUGO Gene Nomenclature Committee at http://www.gene. ucl.ac.uk/nomenclature/) and by the hypothalamic thyrotropin-releasing hormone. A feed-back mechanism exists in which thyroid hormone and retinoic acid can suppress the expression of the TSH gene (Wolf, 2002). In the circulation, $\mathrm{T}_{4}$ is mainly bound to plasma proteins, namely thyroxine-binding globulin, transthyretin (TTR), albumin and lipoproteins (Palha, 2002). Triiodothyronine $\left(T_{3}\right)$, the biologically most active thyroid hormone, derives from $\mathrm{T}_{4}$ deiodination (Bianco et al., 2002). In the periphery, type I deiodinase in the kidney and liver is responsible for producing most of the circulating $\mathrm{T}_{3}$. In the brain, $T_{3}$ is produced for local use by the action of deiodinase type II. Interestingly, deiodinases type I and II are differentially regulated in order to protect the brain from $\mathrm{T}_{3}$ excess or deficiency. In accordance, during hypothyroidism, type I deiodinase is downregulated while type II is upregulated; the opposite occurs in hyperthyroid conditions. Therefore, the activity of deiodinases is a key step to regulate the availability of active $T_{3}$. Inactivation of thyroid hormone is mainly carried out by the action of type III deiodinase, glucoronosyltransferase and sulfotransferases (Leonard and Koehrle, 2000).

Most thyroid-hormone-mediated actions are controlled by transcriptional regulation (Bassett et al., 2003; Yen, 2001). $\mathrm{T}_{3}$ interacts with thyroid hormone receptors (THR) that function as ligand-activated transcription factors. Two genes encode THRs, THRA and THRB, and for each there are splicing variants with distinct developmental and tissue distribution patterns. Within the nucleus, THRs recognize hormone response elements in target genes. For activity, however, they need to heterodimerize. The retinoid X receptor (RXR) is their principal heterodimeric partner. The metabolism of thyroid hormones and retinoids is, therefore, linked through their main mechanism of action at the transcription level. However, as we will see below, other bridges link these two important classes of gene expression modulators.

\subsection{Retinoids}

Vitamin A (retinol) is obtained from the diet and derives either from preformed vitamin A or from provitamin A carotenoids. In the circulation, vitamin A may travel unbound in the form of retinol, which can lead to toxicity (Gimeno et al., 2004), or preferably is either carried in lipoprotein particles in the form of retinyl esters, or as a retinol/retinol-binding protein (RBP) complex bound to TTR. Thus, TTR serves as a carrier for both retinol bound to $\mathrm{RBP}$ and $\mathrm{T}_{4}$ in blood and in cerebrospinal fluid (CSF). In the CSF, TTR may transport retinol to sites where the primary morphogens of the retinoid cascade, the biologically active molecules, 9-cis or all-trans retinoic acid (RA) are synthesized through the action of several hydrolases, transferases and dehydrogenases (particularly the retinaldehyde dehydrogenases, ALDH1A1, 2 and 3) (Gottesman et al., 2001; McCaffery and Drager, 1994) and inactivated by the cytochrome P450 enzymes, CYP26A1, B1 and C1 (Taimi et al., 2004). Retinoid activity is mainly achieved by transcription regulation through interaction with two types of nuclear receptors that display different ligand specificity (Balmer and Blomhoff, 2002). Alltrans RA preferentially binds to RARs (A, B and G), while 9-cis RA binds both RAR and RXRs (A, B and $G$ ). These receptors belong to the same family as the THRs and, as well, heterodimerize and interact with specific response elements on target genes. Interestingly, RXR is a promiscuous partner with RAR, THRs, peroxisome-proliferator-activated receptors, vitamin D receptor (Mackay-Sim et al., 2004) and also nuclear receptors for which no ligand has been discovered, such as the NR4A2 (Wallen-Mackenzie et al., 2003). Thyroid hormones and retinoid pathways are therefore related and influenced by each other, not only because they share blood and CSF specific carriers, but also because their nuclear receptors frequently heterodimerize to regulate gene transcription.

For most of the hormones and vitamins influencing gene expression, studies clearly suggest that these molecules can exert functions independent of their nuclear receptors. While nuclear-transcription-mediated actions take hours to days to manifest, rapid actions outside the nucleus have been reported, demonstrating mechanisms independent of transcription. These can be exerted by interaction of $\mathrm{T}_{4}$ or $\mathrm{T}_{3}$ with plasma membrane receptors, cytoplasm and cell organelles (Bassett et al., 2003; Davis et al., 2002; Weitzel et al., 2003) or through hormone intermediates or metabolites. A novel identified thyroid hormone derivative, 3-iodothyronamine, has been shown, in vitro, to be a potent agonist of the G-proteincoupled trace-amine-associated receptor 1 (TAAR1) (Scanlan et al., 2004). RA is a major modulator of apoptosis, involving gene activation within mitochondria which are independent of the nuclear RARs (Pfahl and Piedrafita, 2003). This suggests that RA analogs might be uniquely successful in the development of therapies (Farooqui et al., 2004) to counter these excessive apoptotic mechanisms that have been proposed as malignant actors in a variety of neuropsychiatric disorders including schizophrenia (Goodman, 1998; LaMantia, 1999; Sharma, 2005), affective disorder (Sakai et al., 2004) and Alzheimer's disease (Corcoran et al., 2004; Etchamendy et al., 2001; Goodman and Pardee, 2003; Ono et al., 2004). In addition, some data also implicate RA in gene expression regulation through a direct role in the activation of transcription factors such as the phosphorylation of cyclic AMP response element binding protein (Canon et al., 2004). Moreover, retinoid and thyroid hormone receptors can act independently of ligands particularly as mediators of cell fate, gene silencing, co-factor recruitment and chromatin remodeling (Weston et al., 2003), all of which processes having been proposed as increasing vulnerability to schizophrenia (Abdolmaleky et al., 2004; Sharma, 2005).

\section{Thyroid hormones, retinoids and schizophrenia}

Thyroid hormones and retinoids are not only essential for the proper development of the central nervous system (Maden, 2002; Morreale de Escobar et al., 2004) but also for the adult 
brain (Bianco et al., 2002; Lane and Bailey, 2005). Several processes that have been identified as pathological in schizophrenia are regulated by retinoids and thyroid hormones. These include differentiation of the cerebellum, axonal migration and myelination (Rodriguez-Pena, 1999), control of lateralization and symmetry of the developing embryo (Vermot and Pourquie, 2005; Vermot et al., 2005), cell survival in adult hippocampus (Crandall et al., 2004), transcriptional regulation of enzymes, receptors and transporters of the neurotransmitter cascades (Balmer and Blomhoff, 2002; Bernal et al., 2003; Smith et al., 2001), such as the dopamine D2 receptor (Samad et al., 1997), and maturation of the limbic regions of the forebrain (Luo et al., 2004). Retinoid deficit leads to defects in lateralization and symmetry and ventricular enlargement (Goodman, 1996b; Kawakami et al., 2005; Vermot and Pourquie, 2005; Vermot et al., 2005). Mice exposed to high levels of retinoic acid during a critical period in early development, corresponding to the second trimester in utero for humans exhibit severely abnormal limbic system-mediated behaviors as adults, e.g., extreme aggressiveness and poor grooming, which may be considered as modeling schizophrenia, although they appear normal as pups (Luo et al., 2004). And, retinoids and thyroid hormone have been directly implicated in the processes of learning and memory (Zoeller and Rovet, 2004), particularly working memory (Wietrzych et al., 2005), which is intricately involved not only in language production but also in schizophrenia (Mitchell and Crow, 2005).

Major thyroid hormone deficiency during pregnancy results in cretinism, while mild hypothyroidism is associated with poorer cognitive development. Even euthyroid hypothyroxinemia during pregnancy has been shown to impair proper neuronal migration in the somatosensory cortex and hippocampus in rodents (Lavado-Autric et al., 2003). This is believed to impair behavior, as recently shown in mice deprived of TTR. These mice are euthyroid hypothyroxinemic but display increased exploratory activity and reduced signs of depressivelike behavior (Sousa et al., 2004). Future studies will address whether TTR-null mice have altered acute startle response as a measure of schizophrenia-like behavior. Follow up of thyroid function throughout pregnancy and evaluation of the psychomotor development of the offspring, possibly until adulthood, would clearly be a more relevant indication of a relationship between thyroid hormones and behavior disorders such as schizophrenia. This is currently ongoing in several laboratories, including ours. In the adult, it is known that thyroid hormone fluctuations are associated with mood alterations, and normal brain metabolism adapts in order to avoid thyroid hormones excess or deprivation (Bianco et al., 2002).

Deficiency of thyroid hormones in neurodevelopment is known to result in impaired proliferation, migration and differentiation of hippocampal and cortical neurons (Auso et al., 2004; Lavado-Autric et al., 2003). The expression of TRH in humans is predominant in the left hemisphere (Borson-Chazot et al., 1986), and asymmetries have been described for several neuroendocrine system, including the hypothalamicthyroid axis (Gerendai and Halasz, 1997). Such pathologies have been demonstrated in schizophrenia (Mitchell and Crow, 2005).

Several studies, cited as follows, have reported thyroid hormone level abnormalities in hospitalized schizophrenic patients, but, in most cases, patients remain clinically euthyroid. Elevated and normal total $\mathrm{T}_{4}$ levels have been reported in drug naive and acute schizophrenic patients and are described to normalize or decrease, respectively, as a response to treatment with different drugs (Baumgartner et al., 2000; Kelly and Conley, 2005; Martinos et al., 1986; Rao et al., 1984; Rinieris et al., 1980). Other studies reported a positive correlation between circulating free $\mathrm{T}_{4}$ and free $\mathrm{T}_{3}$ with severity of disease (Sim et al., 2002). These results are difficult to compare and interpret given the different methodological approaches and patient selection used in each study. Further studies are certainly required to clarify the reasons for altered thyroid hormone circulation levels in schizophrenia. Among these are competition between thyroid hormones and medication for common metabolic pathways, and the downstream effects of therapeutic medication targets on the pituitary-thyroid axis. It is particularly interesting to relate the pituitary-thyroid axis with the dopaminergic hypothesis of schizophrenia. Increased dopaminergic activity inhibits TSH pituitary secretion (Rao et al., 1984), and dopamine blockers result in subclinical hypothyroidism (Magliozzi et al., 1989) while hypothyroidism induces increased dopamine receptor sensitivity (Crocker et al., 1986). A recent report demonstrated that hypothyroid rats are unable to switch the conversion of excitatory to inhibitory hippocampus dopamine receptors, which can be reversed by administration of $\mathrm{T}_{4}$. Therefore, hypothyroidism may compromise glutamatergic transmission and synaptic function (Suzuki et al., 2004). Thyroid hormones have been implicated in other neurotransmitter systems. Studies in mentally healthy individuals showed that the pituitary-thyroid state correlates with central dopaminergic and serotonergic activity (Strawn et al., 2004). Given the distribution pattern of thyroid hormones in the brain and the strong co-localization with the noradrenergic system (Rozanov and Dratman, 1996), Dratman and Gordon have proposed that $\mathrm{T}_{3}$ itself might behave as a neurotransmitter (Dratman and Gordon, 1996). Of relevance here is the finding that 3-iodothyronamine, a recently identified endogenous derivative of thyroid hormones, is able to activate, in vitro, the traceamine-associated receptor, TAAR1 (Scanlan et al., 2004). TAARs are ligand targets of endogenous trace amines and of several psychoactive drugs, including amphetamine derivatives (Bunzow et al., 2001). The finding that a member of the class of thyroid hormones acts as an endogenous ligand for at least one of the TAARs brings a new perspective to the field of thyroid hormone metabolism (Fig. 1) and suggests novel possibilities in terms of causality of and treatment for neurobehavioral disorders (Lindemann and Hoener, 2005).

Retinoids, too, modulate neurotransmission. Not only has the expression of dopamine 2 receptors been shown to be regulated by retinoic acid (Samad et al., 1997), but also single and compound null mutations for the RARB, RXRB and RXRG in mice demonstrate reduced expression of D1 and D2 receptors and impaired dopamine signaling (Krezel et al., 1998). Retinoid analogs have therefore been proposed as candidates in the treatment of schizophrenia (Citver et al., 2002; Goodman, 1998; Sharma, 2005). It is also interesting that a few studies showed the beneficial effect of retinoid agonists in suppressing side effects of antipsychotic drugs such as haloperidol. Specifically, 9-cis retinoic acid has been shown to 
suppress the cataleptic response induced by haloperidol in mice (Ethier et al., 2004a) and the retinoid agonist docosahexaenoic acid reduced haloperidol-induced oral dyskinesias (Ethier et al., 2004b).

Two very convincing studies have shown that nutritional deprivation during early uterine life significantly increases risk of schizophrenia among those so exposed (Susser and Lin, 1992; St Clair et al., 2005). Although vitamin A is not the only nutritional element compromised in cases of starvation, it certainly represents a prime component in all starvation supplemental nutrition programs and should be considered as one of the factors that are compromised during severe famine.

\subsection{Chromosomal loci for schizophrenia}

We will next briefly report evidence that chromosomal regions implicated in schizophrenia harbor genes from the vitamin A and thyroid hormone metabolic cascades. In 1998, a review summarizing the findings that then supported the retinoid hypothesis in schizophrenia was published (Goodman, 1998). That paper lists chromosomal regions, previously implicated in schizophrenia, that contain genes of the retinoid cascade and the retinoic acid receptors. Some of these are within regions that achieved genome-wide significance in linkage studies, while others are considered promising (Lerer et al., 2003; Lewis et al., 2003; Owen et al., 2004). These included four of the six retinoic acid receptors, i.e., RARA on chromosome 17q21.2 (for the cytogenetic locations, we used the updated information available in the UCSC Genome Browser at http://genome.ucsc.edu), RARB on 3p24.2, RXRB on $6 \mathrm{p} 21.32$ and RXRG on 1q23.3 and a variety of the retinoid metabolizing enzymes and carrier proteins, i.e., cellular retinoic-acid-binding protein CRABP2 on 1q23.1, lipoprotein lipase on 8p21.3, RBP1 and RPB2 on 3q23, and ALDH1A1 on 9q21.13. A novel common locus for narrowly defined schizophrenia and bipolar phenotypes at 15q26.3, the locus of ALDH1A3 has recently been reported (Maziade et al., 2005). To date, two association studies have failed to demonstrate significant association of polymorphisms in the retinoid receptors with schizophrenia (Feng et al., 2005; Ishiguro et al., 2002). Feng et al. (Feng et al., 2005) found a non-significant trend towards association identifying the RARB mutation in 4/498 schizophrenia patients vs. 1/509 non-schizophrenia individuals. However, a modestly larger replication study failed to significantly confirm the association of the mutation with the disease. In cases in which the SNP is rare, much larger sample sizes would be needed to achieve sufficient statistical power as has been shown in the work identifying the rare BRCA1 mutation in breast cancer (Friedman et al., 1994).

TAAR1, liganded by the thyroid hormone derivative 3iodothyronamine, is located within the TAAR cluster at chromosome 6q23.2, a region linked to schizophrenia by several genome studies (Levi et al., 2005; Owen et al., 2004; Venken et al., 2005). Several different SNPs in TRAR4/TAAR6 have recently been identified in both schizophrenia (Duan et al., 2004) and bipolar disorder (Abou Jamra et al., 2005). Other genome-wide scan studies, still to be replicated, implicate chromosomal regions harboring several genes involved in thyroid hormone metabolism, namely deiodinase type I on chromosome 1p32.3 (Fallin et al., 2003), THRB on 3p24.2 (Pulver et al., 1995) and UDP glucuronosyltransferases on 2q37.1 (Lerer et al., 2003; Wijsman et al., 2003). Therefore, the loci of many genes of the retinoid and thyroid hormone metabolic cascades and genes whose expression they regulate have been often implicated in schizophrenia. Relevant support for this involvement comes from studies in rodents in which the expression of nuclear receptors and genes involved in thyroid hormone and retinoid metabolism is influenced by subchronic and acute treatment with drugs such as haloperidol and clozapine (Eravci et al., 2000; Langlois et al., 2001; Werme et al., 2000).

\section{Schizophrenia candidate genes regulated by retinoic acid and thyroid hormones}

The genetic cascades that make ligands available to activate nuclear transcription factors at specific times in development and at specific brain locations are complex. Normal allelic variants in any of the metabolic enzymes of the cascade or of the ligand transporters could combine to alter ligand availability. Or nutrient fluctuations due to dietary or infectious insults could synergize with this variety of alleles to finally tip the careful balance between deprivation and toxicity, impacting on the genetic expression of target schizophrenia candidate genes. Or gene silencing through methylation or chromatin remodeling (Sharma, 2005) could impact numerous candidate genes co-localized near the nuclear transcription factors that control the expression of these candidates (Goodman and Pardee, 2000).

Retinoid and thyroid hormone involvement in susceptibility to schizophrenia might result either from mutations or polymorphisms in genes of their metabolism or whose expression they regulate but may also result from the altered expression of these normal genes. Few studies to date have focused on the search for polymorphisms in these genes. An association with thyroid disease and schizophrenia has been reported with a polymorphism on the HOPA gene that codes for a nuclear receptor coactivator (DeLisi et al., 2000; Spinks et al., 2004). NR4A2, the human homolog of mouse Nurr1, is another interesting gene that codes for an orphan nuclear receptor. It heterodimerizes with RXR, and its function is essential for the development of the dopaminergic system (Zetterström et al., 1997). Mutations on the NR4A2 gene have been described in Swedish, but not American Caucasian patients with schizophrenia (Buervenich et al., 2000), and in patients of European descent with Parkinson's disease (Le et al., 2003). We were unable to find any of these mutations in Portuguese or Brazilian patients with schizophrenia (Ruano et al., 2004). Ongoing studies in our laboratory focus on the search for polymorphisms in other candidate genes of these cascades.

\subsection{Retinoids and estrogens}

The complexity and diversity of pathways in which retinoids and thyroid hormones are involved result from their ability to interact with several other hormonal and neurotransmitter pathways previously implicated in schizophrenia. Among these are estrogens, which have been thought to be 
protective in schizophrenia (Rao and Kolsch, 2003) since males develop schizophrenia of greater severity and at a significantly earlier age than females, although the estrogen-specific mechanism involved is not well understood. It has now been shown that estrogen directly induces the expression of the RA-synthesizing enzymes, retinol dehydrogenase and retinaldehyde dehydrogenase 2 and the RA transporter CRABP2 in epithelial and stromal cells of the liver (Li et al., 2004). If this proves to be the case in other cell types, a novel connection could be envisaged for the brain. This connection suggests coordinated activation and subsequent signaling by estrogen and retinoic acid in the epithelial and stromal cells of the brain, i.e., the choroid plexus, where lipid retinoid is carried across the CSF/brain barrier and the meninges where retinaldehyde dehydrogenase is synthesized (Crandall et al., 2004). Upon crossing the CSF/brain barrier, RA synthesis occurs in areas bordering the limbic system of the hippocampus and the dorsolateral prefrontal cortex (Smith et al., 2001; Yamamoto et al., 1998), parts of the brain primarily involved in schizophrenia (Antonova et al., 2004). Increased retinoid signaling in estrogenreplete females could account in part for the protective role of retinoids and estrogen in this group of schizophrenia patients.

\subsection{Altered gene expression in schizophrenia}

Microarray analysis of post-mortem brain tissue from patients with schizophrenia has revealed alterations in the expression pattern of genes belonging to several neurotransmitter, signal transduction and metabolic pathways. However, care should be taken in interpreting the data obtained in these studies. For the most part, it is still unclear whether altered expression occurs before or after disease onset and whether it is a consequence of medication. It is also possible that the most relevant alterations in gene expression occur before disease onset and no longer are reflected in diseased brain. In any case, these studies are important in proposing mechanisms of disease for further investigation. Of relevance to our discussion, myelination, neurotransmission, signal transduction, synaptic function and mitochondrial activation, processes that are impaired in the schizophrenic brain, are directly or indirectly regulated by thyroid hormones and/or vitamin A. Several candidate genes recently singled out as significantly contributing to increased vulnerability in schizophrenia (Hakak et al., 2001; Hall et al., 2004; Harrison and Weinberger, 2005; Kuromitsu et al., 2001; Shirts and Nimgaonkar, 2004) are directly or indirectly regulated by thyroid hormone and retinoic acid. Among these are ERBB4, the receptor for neuregulin 1 (Offterdinger et al., 1999); neuropeptide $Y$ (Magni, 2003); NOTCH4 (Ye et al., 2004); DRD2 (Samad et al., 1997); PHOX2B, a transcription factor for RGS4 (Grillet et al., 2003; Shoba et al., 2002); dysbindin (through retinoid regulation of the expression of dystrophin-associated protein complex (Ceccarini et al., 2002)); prohormone convertases 1 and 3 (Shen et al., 2004); and amyloid-beta protein (Villa et al., 2004) and myelin-related genes (see below).

Myelination is a paradigmatic example of the temporal involvement of thyroid hormones and retinoids in regulating an essential neuronal process that has been implicated in schizophrenia. Myelination is a neurodevelopmental pathway regulated by thyroid hormones (Rodriguez-Pena, 1999). It has been argued that a defect in myelination of key corticolimbic pathways could be related to development of schizophrenia (Keshavan and Hogarty, 1999), and altered expression of myelin-related genes has been found in post-mortem schizophrenic brains (Hakak et al., 2001). Myelination is a process that continues into early adulthood and into midlife. Interestingly, the observation that males have an earlier onset of schizophrenia might be a consequence of their delay in myelination during adolescence (Keshavan and Hogarty, 1999). Hypothyroidism is associated with delayed myelination in several brain regions (Farsetti et al., 1992; Ibarrola and Rodriguez-Pena, 1997). Myelination may later be normalized through subsequent upregulation of expression of myelin basic protein, the transcription of which is activated by 9-cis RA (Pombo et al., 1999). This is an example of the temporal involvement of several environmental factors in the regulation of essential neuronal processes and in which thyroid hormone and retinoic acid pathways interplay. In a microarray study of chronic schizophrenia, most of the myelinationrelated genes shown to be differentially downregulated, including cyclic nucleotide phosphodiesterase, myelin-associated glycoprotein, transferrin and ERBB3 (Hakak et al., 2001; Yang et al., 2005) are, themselves, regulated by retinoic acid and thyroid hormone.

New findings add direct and independent molecular support to the hypothesis that retinoids and thyroid hormones may increase vulnerability to schizophrenia: (1) the recent discovery of the specific differential upregulation of RARA in granule cells of the dentate gyrus in schizophrenia (Rioux and Arnold, 2005); (2) the report that RBP4 is highly expressed in association and limbic cortex of adult primate brains (Komatsu et al., 2005), regions specifically implicated in schizophrenia (Heinz et al., 2003); (3) a recent microarray study showing the retinoic acid receptor as a top functional gene group altered in schizophrenia (Middleton et al., 2005); (4) the observation that albumin and ALDH1A1, proteins involved in the transport and synthesis of thyroid hormone and RA, respectively, are highly significantly differentially expressed in a microarray study of schizophrenia brains (Goodman, 2005; Prabakaran et al., 2004); (5) the independent immunohistochemical confirmation that ALDH1A1 is decreased in the ventral tegmental area in schizophrenia (Galter et al., 2003); (6) evidence showing that the drug, Accutane, which is a retinoic acid analogue, causes altered brain function and decreased metabolism in the orbitofrontal cortex of Accutane-treated acne patients compared to acne patients not so treated (Bremner et al., 2005); and (7) the demonstration that Accutane causes decrease in hippocampal size and learning ability in exposed mice (Crandall et al., 2004).

\section{Conclusions}

The available information on candidate genes involved in schizophrenia, both at the level of genetic mutations or as a consequence of altered expression of normal genes, suggests hormones and vitamins as potential bridges between the genetic and environmental components of the disease. It is 
presently clear that several pathways and cross-talk between retinoids, thyroid hormones and other members of the nuclear receptor superfamily interact intimately and completely with environmental factors influencing the incorporation of hormones and vitamins into the organism, thus making these systems equally sensitive to both "nurtural" and "natural" factors. As others, we believe that investigating entire biological pathways rather than single genes will greatly contribute to more precise understanding of their potential involvement in schizophrenia. Much further laboratory work must be completed before it will be possible to synthesize the implications of the hard data now beginning to emerge which strongly suggest that dysregulation of the retinoid and/or thyroid hormone cascades may represent common underlying pathways which defectively cross-talk in the development of schizophrenia.

\section{Acknowledgments}

The present work is supported by Fundação para a Ciência e Tecnologia/FEDER (Portugal) grant POCTI/MGI/35837.

\section{REF ERENCES}

Abdolmaleky, H.M., Smith, C.L., Faraone, S.V., Shafa, R., Stone, W., Glatt, S.J., Tsuang, M.T., 2004. Methylomics in psychiatry: modulation of gene-environment interactions may be through DNA methylation. Am. J. Med. Genet. 127, 51-59.

Abou Jamra, R., Sircar, I., Becker, T., Freudenberg-Hua, Y., Ohlraun, S., Freudenberg, J., Brockschmidt, F., Schulze, T.G., Gross, M., Spira, F., Deschner, M., Schmal, C., Maier, W., Propping, P., Rietschel, M., Cichon, S., Nothen, M.M., Schumacher, J., 2005. A family-based and case-control association study of trace amine receptor genes on chromosome 6q23 in bipolar affective disorder. Mol. Psychiatry 10, 618-620.

Antonova, E., Sharma, T., Morris, R., Kumari, V., 2004. The relationship between brain structure and neurocognition in schizophrenia: a selective review. Schizophr. Res. 70, 117-145.

Auso, E., Lavado-Autric, R., Cuevas, E., Del Rey, F.E., Morreale De Escobar, G., Berbel, P., 2004. A moderate and transient deficiency of maternal thyroid function at the beginning of fetal neocorticogenesis alters neuronal migration. Endocrinology 145 , 4037-4047.

Balmer, J.E., Blomhoff, R., 2002. Gene expression regulation by retinoic acid. J. Lipid Res. 43, 1773-1808.

Bassett, J.H., Harvey, C.B., Williams, G.R., 2003. Mechanisms of thyroid hormone receptor-specific nuclear and extra nuclear actions. Mol. Cell. Endocrinol. 213, 1-11.

Baumgartner, A., Pietzcker, A., Gaebel, W., 2000. The hypothalamic-pituitary-thyroid axis in patients with schizophrenia. Schizophr. Res. 44, 233-243.

Bernal, J., 2002. Action of thyroid hormone in brain. J. Endocrinol. Invest. 25, 268-288.

Bernal, J., Guadano-Ferraz, A., Morte, B., 2003. Perspectives in the study of thyroid hormone action on brain development and function. Thyroid 13, 1005-1012.

Bianco, A.C., Salvatore, D., Gereben, B., Berry, M.J., Larsen, P.R., 2002. Biochemistry, cellular and molecular biology, and physiological roles of the iodothyronine selenodeiodinases. Endocr. Rev. 23, 38-89.

Borson-Chazot, F., Jordan, D., Fevre-Montange, M., Kopp, N., Tourniaire, J., Rouzioux, J.M., Veisseire, M., Mornex, R., 1986.
TRH and LH-RH distribution in discrete nuclei of the human hypothalamus: evidence for a left prominence of TRH. Brain Res. 382, 433-436.

Bremner, J.D., Fani, N., Ashraf, A., Votaw, J.R., Brummer, M.E., Cummins, T., Vaccarino, V., Goodman, M.M., Reed, L., Siddiq, S., Nemeroff, C.B., 2005. Functional brain imaging alterations in acne patients treated with isotretinoin. Am. J. Psychiatry 162, 983-991.

Buckland, P.R., Hoogendoorn, B., Guy, C.A., Coleman, S.L., Smith, S. K., Buxbaum, J.D., Haroutunian, V., O’Donovan, M.C., 2004. A high proportion of polymorphisms in the promoters of brain expressed genes influences transcriptional activity. Biochim. Biophys. Acta 1690, 238-249.

Buervenich, S., Carmine, A., Arvidsson, M., Xiang, F., Zhang, Z., Sydow, O., Jonsson, E.G., Sedvall, G.C., Leonard, S., Ross, R.G., Freedman, R., Chowdari, K.V., Nimgaonkar, V.L., Perlmann, T., Anvret, M., Olson, L., 2000. NURR1 mutations in cases of schizophrenia and manic-depressive disorder. Am. J. Med. Genet. 96, 808-813.

Bunzow, J.R., Sonders, M.S., Arttamangkul, S., Harrison, L.M., Zhang, G., Quigley, D.I., Darland, T., Suchland, K.L., Pasumamula, S., Kennedy, J.L., Olson, S.B., Magenis, R.E., Amara, S.G., Grandy, D.K., 2001. Amphetamine, 3,4-methylenedioxymethamphetamine, lysergic acid diethylamide, and metabolites of the catecholamine neurotransmitters are agonists of a rat trace amine receptor. Mol. Pharmacol. 60, 1181-1188.

Canon, E., Cosgaya, J.M., Scsucova, S., Aranda, A., 2004. Rapid effects of retinoic acid on CREB and ERK phosphorylation in neuronal cells. Mol. Biol. Cell 15, 5583-5592.

Ceccarini, M., Macioce, P., Panetta, B., Petrucci, T.C., 2002. Expression of dystrophin-associated proteins during neuronal differentiation of P19 embryonal carcinoma cells. Neuromuscul. Disord. 12, 36-48.

Citver, A.S., Shields, A.M., Ciaccia, L.M., Schulingkamp, R.J., Raffa, R.B., 2002. Indirect modulation of dopamine D2 receptors as potential pharmacotherapy for schizophrenia: III. Retinoids. J. Clin. Pharm. Ther. 27, 161-168.

Corcoran, J.P., So, P.L., Maden, M., 2004. Disruption of the retinoid signalling pathway causes a deposition of amyloid beta in the adult rat brain. Eur. J. Neurosci. 20, 896-902.

Crandall, J., Sakai, Y., Zhang, J., Koul, O., Mineur, Y., Crusio, W.E., McCaffery, P., 2004. 13-cis-retinoic acid suppresses hippocampal cell division and hippocampal-dependent learning in mice. Proc. Natl. Acad. Sci. U. S. A. 101, 5111-5116.

Crocker, A.D., Overstreet, D.H., Crocker, J.M., 1986. Hypothyroidism leads to increased dopamine receptor sensitivity and concentration. Pharmacol. Biochem. Behav. 24, 1593-1597.

Davis, P.J., Tillmann, H.C., Davis, F.B., Wehling, M., 2002. Comparison of the mechanisms of nongenomic actions of thyroid hormone and steroid hormones. J. Endocrinol. Invest. 25, 377-388.

DeLisi, L.E., Smith, A.B., Razi, K., Stewart, J., Wang, Z., Sandhu, H.K., Philibert, R.A., 2000. Investigation of a candidate gene for schizophrenia on Xq13 previously associated with mental retardation and hypothyroidism. Am. J. Med. Genet. 96, 398-403.

Dratman, M.B., Gordon, J.T., 1996. Thyroid hormones as neurotransmitters. Thyroid 6, 639-647.

Duan, J., Martinez, M., Sanders, A.R., Hou, C., Saitou, N., Kitano, T., Mowry, B.J., Crowe, R.R., Silverman, J.M., Levinson, D.F., Gejman, P.V., 2004. Polymorphisms in the trace amine receptor 4 (TRAR4) gene on chromosome 6q23.2 are associated with susceptibility to schizophrenia. Am. J. Hum. Genet. 75, 624-638.

Eravci, M., Pinna, G., Meinhold, H., Baumgartner, A., 2000. Effects of pharmacological and nonpharmacological treatments on thyroid hormone metabolism and concentrations in rat brain. Endocrinology 141, 1027-1040.

Etchamendy, N., Enderlin, V., Marighetto, A., Vouimba, R.M., Pallet, V., Jaffard, R., Higueret, P., 2001. Alleviation of a selective age- 
related relational memory deficit in mice by pharmacologically induced normalization of brain retinoid signaling. J. Neurosci. 21, 6423-6429.

Ethier, I., Beaudry, G., St-Hilaire, M., Milbrandt, J., Rouillard, C., Levesque, D., 2004a. The transcription factor NGFI-B (Nur77) and retinoids play a critical role in acute neuroleptic-induced extrapyramidal effect and striatal neuropeptide gene expression. Neuropsychopharmacology 29, 335-346.

Ethier, I., Kagechika, H., Shudo, K., Rouillard, C., Levesque, D., 2004b. Docosahexaenoic acid reduces haloperidol-induced dyskinesias in mice: involvement of Nur77 and retinoid receptors. Biol. Psychiatry 56, 522-526.

Fallin, M.D., Lasseter, V.K., Wolyniec, P.S., McGrath, J.A., Nestadt, G., Valle, D., Liang, K.Y., Pulver, A.E., 2003. Genomewide linkage scan for schizophrenia susceptibility loci among Ashkenazi Jewish families shows evidence of linkage on chromosome 10q22. Am. J. Hum. Genet. 73, 601-611.

Farooqui, A.A., Antony, P., Ong, W.Y., Horrocks, L.A., Freysz, L., 2004. Retinoic acid-mediated phospholipase A2 signaling in the nucleus. Brain Res. Brain Res. Rev. 45, 179-195.

Farsetti, A., Desvergne, B., Hallenbeck, P., Robbins, J., Nikodem, V. M., 1992. Characterization of myelin basic protein thyroid hormone response element and its function in the context of native and heterologous promoter. J. Biol. Chem. 267, 15784-15788.

Feng, J., Chen, J., Yan, J., Jones, I.R., Craddock, N., Cook Jr., E.H., Goldman, D., Heston, L.L., Sommer, S.S., 2005. Structural variants in the retinoid receptor genes in patients with schizophrenia and other psychiatric diseases. Am. J. Med. Genet. 133, 50-53.

Friedman, L.S., Ostermeyer, E.A., Lynch, E.D., Szabo, C.I., Anderson, L.A., Dowd, P., Lee, M.K., Rowell, S.E., Boyd, J., King, M.C., 1994. The search for BRCA1. Cancer Res. 54, 6374-6382.

Galter, D., Buervenich, S., Carmine, A., Anvret, M., Olson, L., 2003. ALDH1 mRNA: presence in human dopamine neurons and decreases in substantia nigra in Parkinson's disease and in the ventral tegmental area in schizophrenia. Neurobiol. Dis. 14, 637-647.

Gerendai, I., Halasz, B., 1997. Neuroendocrine asymmetry. Front. Neuroendocrinol. 18, 354-381.

Gimeno, A., Zaragoza, R., Vivo-Sese, I., Vina, J.R., Miralles, V.J., 2004. Retinol, at concentrations greater than the physiological limit, induces oxidative stress and apoptosis in human dermal fibroblasts. Exp. Dermatol. 13, 45-54.

Goodman, A.B., 1996a. Retinoid dysregulation may result in abnormal expression of glutamic acid decarboxylase in schizophrenia. Arch. Gen. Psychiatry 53, 653.

Goodman, A.B., 1996b. Congenital anomalies in relatives of schizophrenic probands may indicate a retinoid pathology. Schizophr Res. 19, 163-170.

Goodman, A.B., 1998. Three independent lines of evidence suggest retinoids as causal to schizophrenia. Proc. Natl. Acad. Sci. U. S. A. 95, 7240-7244.

Goodman, A.B., 2005. Microarray results suggest altered transport and lowered synthesis of retinoic acid in schizophrenia. Mol. Psychiatry 10, 620-621.

Goodman, A.B., Pardee, A.B., 2000. Meeting report; "Molecular neurobiological mechanisms in schizophrenia: seeking a synthesis," April 11-14, 1999. Biol. Psychiatry 48, 173-183.

Goodman, A.B., Pardee, A.B., 2003. Evidence for defective retinoid transport and function in late onset Alzheimer's disease. Proc. Natl. Acad. Sci. U. S. A. 100, 2901-2905.

Gottesman, M.E., Quadro, L., Blaner, W.S., 2001. Studies of vitamin A metabolism in mouse model systems. Bioessays 23, 409-419.

Grillet, N., Dubreuil, V., Dufour, H.D., Brunet, J.F., 2003. Dynamic expression of RGS4 in the developing nervous system and regulation by the neural type-specific transcription factor Phox2b. J. Neurosci. 23, 10613-10621.
Hakak, Y., Walker, J.R., Li, C., Wong, W.H., Davis, K.L., Buxbaum, J. D., Haroutunian, V., Fienberg, A.A., 2001. Related genomewide expression analysis reveals dysregulation of myelination-related genes in chronic schizophrenia. Proc. Natl. Acad. Sci. U. S. A. $98,4746-4751$.

Hall, D., Gogos, J.A., Karayiorgou, M., 2004. The contribution of three strong candidate schizophrenia susceptibility genes in demographically distinct populations. Genes Brain Behav. 3, 240-248.

Harrison, P.J., Weinberger, D.R., 2005. Schizophrenia genes, gene expression, and neuropathology: on the matter of their convergence. Mol. Psychiatry 10, 40-68.

Heinz, A., Romero, B., Gallinat, J., Juckel, G., Weinberger, D.R., 2003. Molecular brain imaging and the neurobiology and genetics of schizophrenia. Pharmacopsychiatry 36, S152-S157.

Hoogendoorn, B., Coleman, S.L., Guy, C.A., Smith, K., Bowen, T., Buckland, P.R., O'Donovan, M.C., 2003. Functional analysis of human promoter polymorphisms. Hum. Mol. Genet. 12, 2249-2254.

Ibarrola, N., Rodriguez-Pena, A., 1997. Hypothyroidism coordinately and transiently affects myelin protein gene expression in most rat brain regions during postnatal development. Brain Res. 752, 285-293.

Ishiguro, H., Okubo, Y., Ohtsuki, T., Yamakawa-Kobayashi, K., Arinami, T., 2002. Mutation analysis of the retinoid $\mathrm{X}$ receptor beta, nuclear-related receptor 1 , and peroxisome proliferatoractivated receptor alpha genes in schizophrenia and alcohol dependence: possible haplotype association of nuclear-related receptor 1 gene to alcohol dependence. Am. J. Med. Genet. 114, 15-23.

Kawakami, Y., Raya, A., Raya, R.M., Rodriguez-Esteban, C., Belmonte, J.C., 2005. Retinoic acid signalling links left-right asymmetric patterning and bilaterally symmetric somitogenesis in the zebrafish embryo. Nature 435, 165-171.

Kelly, D.L., Conley, R.R., 2005. Thyroid function in treatmentresistant schizophrenia patients treated with quetiapine, risperidone, or fluphenazine. J. Clin. Psychiatry 66, 80-84.

Keshavan, M.S., Hogarty, G.E., 1999. Brain maturational processes and delayed onset in schizophrenia. Dev. Psychopathol. 11, 525-543.

Komatsu, Y., Watakabe, A., Hashikawa, T., Tochitani, S., Yamamori, T., 2005. Retinol-binding protein gene is highly expressed in higher-order association areas of the primate neocortex. Cereb. Cortex 15, 96-108.

Krezel, W., Ghyselinck, N., Samad, T.A., Dupe, V., Kastner, P., Borrelli, E., Chambon, P., 1998. Impaired locomotion and dopamine signaling in retinoid receptor mutant mice. Science 279, 863-867.

Kuromitsu, J., Yokoi, A., Kawai, T., Nagasu, T., Aizawa, T., Haga, S. Ikeda, K., 2001. Reduced neuropeptide Y mRNA levels in the frontal cortex of people with schizophrenia and bipolar disorder. Brain Res. Gene Expression Patterns 1, 17-21.

LaMantia, A.S., 1999. Forebrain induction, retinoic acid, and vulnerability to schizophrenia: insights from molecular and genetic analysis in developing mice. Biol. Psychiatry 46, 19-30.

Lane, M.A., Bailey, S.J., 2005. Role of retinoid signalling in the adult brain. Prog. Neurobiol. 75, 275-293.

Langlois, M.C., Beaudry, G., Zekki, H., Rouillard, C., Levesque, D., 2001. Impact of antipsychotic drug administration on the expression of nuclear receptors in the neocortex and striatum of the rat brain. Neuroscience 106, 117-128.

Lavado-Autric, R., Auso, E., Garcia-Velasco, J.V., Arufe Mdel, C., Escobar del Rey, F., Berbel, P., Morreale de Escobar, G., 2003. Early maternal hypothyroxinemia alters histogenesis and cerebral cortex cytoarchitecture of the progeny. J. Clin. Invest. 111, 1073-1082.

Le, W.D., Xu, P., Jankovic, J., Jiang, H., Appel, S.H., Smith, R.G., Vassilatis, D.K., 2003. Mutations in NR4A2 associated with familial Parkinson disease. Nat. Genet. 33, 85-89. 
Leonard, J.L., Koehrle, J., 2000. Intracellular pathways of iodothyronine metabolism. In: Braverman, L.E., Utiger, R.D. (Eds.), The Thyroid. Lippincott Williams and Wilkins, Philadelphia, pp. 136-173.

Lerer, B., Segman, R.H., Hamdan, A., Kanyas, K., Karni, O., Kohn, Y., Korner, M., Lanktree, M., Kaadan, M., Turetsky, N., Yakir, A., Kerem, B., Macciardi, F., 2003. Genome scan of Arab Israeli families maps a schizophrenia susceptibility gene to chromosome 6q23 and supports a locus at chromosome 10q24. Mol. Psychiatry 8, 488-498.

Levi, A., Kohn, Y., Kanyas, K., Amann, D., Pae, C.U., Hamdan, A., Segman, R.H., Avidan, N., Karni, O., Korner, M., Jun, T.Y., Beckmann, J.S., Macciardi, F., Lerer, B., 2005. Fine mapping of a schizophrenia susceptibility locus at chromosome 6q23: increased evidence for linkage and reduced linkage interval. Eur. J. Hum. Genet. 13, 763-771.

Lewis, C.M., Levinsonm, D.F., Wisem, L.H., DeLisi, L.E., Straub, R.E., Hovatta, I., Williams, N.M., Schwab, S.G., Pulver, A.E., Faraone, S.V., Brzustowicz, L.M., Kaufmann, C.A., Garver, D.L., Gurling, H.M., Lindholm, E., Coon, H., Moises, H.W., Byerley, W., Shaw, S. H., Mesen, A., Sherrington, R., O'Neill, F.A., Walsh, D., Kendler, K.S., Ekelund, J., Paunio, T., Lonnqvist, J., Peltonen, L., O’Donovan, M.C., Owen, M.J., Wildenauer, D.B., Maier, W., Nestadt, G., Blouin, J.L., Antonarakis, S.E., Mowry, B.J., Silverman, J.M., Crowe, R.R., Cloninger, C.R., Tsuang, M.T., Malaspina, D., Harkavy-Friedman, J.M., Svrakic, D.M., Bassett, A.S., Holcomb, J., Kalsi, G., McQuillin, A., Brynjolfson, J., Sigmundsson, T., Petursson, H., Jazin, E., Zoega, T., Helgason, T., 2003. Genome scan meta-analysis of schizophrenia and bipolar disorder, part II: schizophrenia. Am. J. Hum. Genet. 73, 34-48.

Li, X.H., Kakkad, B., Ong, D.E., 2004. Estrogen directly induces expression of retinoic acid biosynthetic enzymes, compartmentalized between the epithelium and underlying stromal cells in rat uterus. Endocrinology 145, 4756-4762.

Lindemann, L., Hoener, M.C., 2005. A renaissance in trace amines inspired by a novel GPCR family. Trends Pharmacol. Sci. 26, 274-281.

Luo, T., Wagner, E., Crandall, J.E., Drager, U.C., 2004. A retinoic-acid critical period in the early postnatal mouse brain. Biol. Psychiatry 56, 971-980.

Mackay-Sim, A., Feron, F., Eyles, D., Burne, T., McGrath, J., 2004. Schizophrenia, vitamin $\mathrm{D}$, and brain development. Int. Rev. Neurobiol. 59, 351-380.

Maden, M., 2002. Retinoid signalling in the development of the central nervous system. Nat. Rev., Neurosci. 3, 843-853.

Magliozzi, J.R., Gold, A., Laubly, J.N., 1989. Effect of oral administration of haloperidol on plasma thyrotropin concentrations in men. Psychoneuroendocrinology 14, 125-130.

Magni, P., 2003. Hormonal control of the neuropeptide Y system. Curr. Protein Pept. Sci. 4, 45-57.

Martinos, A., Rinieris, P., Papachristou, D.N., Souvatzoglou, A., Koutras, D.A., Stefanis, C., 1986. Effects of six weeks' neuroleptic treatment on the pituitary-thyroid axis in schizophrenic patients. Neuropsychobiology 16, 72-77.

Maziade, M., Roy, M.A., Chagnon, Y.C., Cliché, D., Fournier, J.P., Montgrain, N., Dion, C., Lavallee, J.C., Garneau, Y., Gingras, N., Nicole, L., Pires, A., Ponton, A.M., Potvin, A., Wallot, H., Merette, C., 2005. Shared and specific susceptibility loci for schizophrenia and bipolar disorder: a dense genome scan in Eastern Quebec families. Mol. Psychiatry 10, 486-499.

McCaffery, P., Drager, U.C., 1994. High levels of a retinoic acidgenerating dehydrogenase in the meso-telencephalic dopamine system. Proc. Natl. Acad. Sci. U. S. A. 91, 7772-7776.

Middleton, F.A., Pato, C.N., Gentile, K.L., McGann, L., Brown, A. M., Trauzzi, M., Diab, H., Morley, C.P., Medeiros, H., Macedo, A., Azevedo, M.H., Pato, M.P., 2005. Gene expression analysis of peripheral blood leukocytes from discordant sib-pairs with schizophrenia and bipolar disorder reveals points of convergence between genetic and functional genomic approaches. Am. J. Med. Genet., Part B Neuropsychiatr. Genet. 136, 12-25.

Mitchell, R.L., Crow, T.J., 2005. Right hemisphere language functions and schizophrenia: the forgotten hemisphere? Brain 128, 963-978.

Morreale de Escobar, G., Obregon, M.J., Escobar del Rey, F., 2004. Role of thyroid hormone during early brain development. Eur. J. Endocrinol. 151, U25-U37.

Nobel, S., Abrahmsen, L., Oppermann, U., 2001. Metabolic conversion as a pre-receptor control mechanism for lipophilic hormones. Eur. J. Biochem. 268, 4113-4125.

Offterdinger, M., Schneider, S.M., Huber, H., Grunt, T.W., 1999. Expression of c-erbB-4/HER4 is regulated in T47D breast carcinoma cells by retinoids and vitamin D3. Biochem. Biophys. Res. Commun. 258, 559-564.

Ono, K., Yoshiike, Y., Takashima, A., Hasegawa, K., Naiki, H., Yamada, M., 2004. Vitamin A exhibits potent antiamyloidogenic and fibril-destabilizing effects in vitro. Exp. Neurol. 189, 380-392.

Owen, M.J., Williams, N.M., O'Donovan, M.C., 2004. The molecular genetics of schizophrenia: new findings promise new insights. Mol. Psychiatry 9, 14-27.

Ozer, S., Ulusahin, A., Ulusoy, S., Okur, H., Coskun, T., Tuncali, T., Gogus, A., Akarsu, A.N., 2004. Is vitamin D hypothesis for schizophrenia valid? Independent segregation of psychosis in a family with vitamin-D-dependent rickets type IIA. Prog. Neuro-Psychopharmacol. Biol. Psychiatry 28, 255-266.

Palha, J.A., 2002. Transthyretin as a thyroid hormone carrier: a function revisited. Clin. Chem. Lab. Med. 40, 1292-1300.

Perkins, D.O., Jeffries, C., Sullivan, P., 2005. Expanding the 'central dogma': the regulatory role of nonprotein coding genes and implications for the genetic liability to schizophrenia. Mol. Psychiatry 10, 69-78.

Pfahl, M., Piedrafita, F.J., 2003. Retinoid targets for apoptosis induction. Oncogene 22, 9058-9062.

Pombo, P.M., Barettino, D., Ibarrola, N., Vega, S., Rodriguez-Pena, A., 1999. Stimulation of the myelin basic protein gene expression by 9 -cis-retinoic acid and thyroid hormone: activation in the context of its native promoter. Brain Res. Mol. Brain Res. 64, 92-100.

Prabakaran, S., Swatton, J.E., Ryan, M.M., Huffaker, S.J., Huang, J.T., Griffin, J.L., Wayland, M., Freeman, T., Dudbridge, F., Lilley, K.S., Karp, N.A., Hester, S., Tkachev, D., Mimmack, M.L., Yolken, R.H., Webster, M.J., Torrey, E.F., Bahn, S., 2004. Mitochondrial dysfunction in schizophrenia: evidence for compromised brain metabolism and oxidative stress. Mol. Psychiatry 9, 684-697.

Pulver, A.E., Lasseter, V.K., Kasch, L., Wolyniec, P., Nestadt, G., Blouin, J.L., Kimberland, M., Babb, R., Vourlis, S., Chen, H., Lalioti, M., Morris, M.A., Karayiorgou, M., Ott, J., Meyers, D., Antonarakis, S.E., Housman, D., Kazazian, H.H., 1995. Schizophrenia: a genome scan targets chromosomes $3 p$ and $8 p$ as potential sites of susceptibility genes. Am. J. Med. Genet. 60, 252-260.

Rao, M.L., Kolsch, H., 2003. Effects of estrogen on brain development and neuroprotection-Implications for negative symptoms in schizophrenia. Psychoneuroendocrinology 28, 83-96.

Rao, M.L., Gross, G., Huber, G., 1984. Altered interrelationship of dopamine, prolactin, thyrotropin and thyroid hormone in schizophrenic patients. Eur. Arch. Psychiatr. Neurol. Sci. 234, 8-12.

Rinieris, P., Christodoulou, G.N., Souvatzoglou, A., Koutras, D.A., Stefanis, C., 1980. Free-thyroxine index in schizophrenic patients before and after neuroleptic treatment. Neuropsychobiology 6, 29-33.

Rioux, L., Rioux and Arnold, S.E., 2005. The expression of retinoic acid receptor alpha is increased in the granule cells of the dentate gyrus in schizophrenia. Psychiatry Res. 133, 13-21.

Rodriguez-Pena, A., 1999. Oligodendrocyte development and thyroid hormone. J. Neurobiol. 40, 497-512. 
Rozanov, C.B., Dratman, M.B., 1996. Immunohistochemical mapping of brain triiodothyronine reveals prominent localization in central noradrenergic systems. Neuroscience 74, 897-915.

Ruano, D., Macedo, A., Dourado, A., Soares, M.J., Valente, J., Coelho, I., Santos, V., Azevedo, M.H., Goodman, A., Hutz, M.H., Gama, C., Lobato, M.I., Belmonte-de-Abreu, P., Palha, J.A., 2004. NR4A2 and schizophrenia: lack of association in a Portuguese/ Brazilian study. Am. J. Med. Genet. 128B, 41-45.

Sakai, Y., Crandall, J.E., Brodsky, J., McCaffery, P., 2004. 13-cis retinoic acid (accutane) suppresses hippocampal cell survival in mice. Ann. N. Y. Acad. Sci. 1021, 436-440.

Samad, T.A., Krezel, W., Chambon, P., Borrelli, E., 1997. Regulation of dopaminergic pathways by retinoids: activation of the D2 receptor promoter by members of the retinoic acid receptorretinoid X receptor family. Proc. Natl. Acad. Sci. U. S. A. 94, 14349-14354.

Scanlan, T.S., Suchland, K.L., Hart, M.E., Chiellini, G., Huang, Y., Kruzich, P.J., Frascarelli, S., Crossley, D.A., Bunzow, J.R., RoncaTestoni, S., Lin, E.T., Hatton, D., Zucchi, R., Grandy, D.K., 2004. 3Iodothyronamine is an endogenous and rapid-acting derivative of thyroid hormone. Nat. Med. 10, 638-642.

Sharma, R.P., 2005. Schizophrenia, epigenetics and ligand-activated nuclear receptors: a framework for chromatin therapeutics. Schizophr. Res. 72, 79-90.

Shen, X., Li, Q.L., Brent, G.A., Friedman, T.C., 2004. Thyroid hormone regulation of prohormone convertase 1 (PC1): regional expression in rat brain and in vitro characterization of negative thyroid hormone response elements. J. Mol. Endocrinol. 33, 21-33.

Shirts, B.H., Nimgaonkar, V., 2004. The genes for schizophrenia: finally a breakthrough? Curr. Psychiatry Rep. 6, 303-312.

Shoba, T., Dheen, S.T., Tay, S.S., 2002. Retinoic acid influences Phox2 expression of cardiac ganglionic cells in the developing rat heart. Neurosci. Lett. 321, 41-44.

Sim, K., Chong, S.A., Chan, Y.H., Lum, W.M., 2002. Thyroid dysfunction in chronic schizophrenia within a state psychiatric hospital. Ann. Acad. Med. Singap. 31, 641-644.

Smith, D., Wagner, E., Koul, O., McCaffery, P., Drager, U.C., 2001. Retinoic acid synthesis for the developing telencephalon. Cereb. Cortex 11, 894-905.

Sousa, J.C., Grandela, C., Fernandez-Ruiz, J., de Miguel, R., de Sousa, L., Magalhaes, A.I., Saraiva, M.J., Sousa, N., Palha, J.A., 2004. Transthyretin is involved in depression-like behaviour and exploratory activity. J. Neurochem. 88, 1052-1058.

Spinks, R., Sandhu, H.K., Andreasen, N.C., Philibert, R.A., 2004. Association of the HOPA12bp allele with a large X-chromosome haplotype and positive symptom schizophrenia. Am. J. Med. Genet. 127, 20-27.

St Clair, D., Xu, M., Wang, P., Yu, Y., Fang, Y., Zhang, F., Zheng, X., Gu, N., Feng, G., Sham, P., He, L., 2005. Rates of adult schizophrenia following prenatal exposure to the Chinese famine of 1959-1961. JAMA 294, 557-562.

Strawn, J.R., Ekhator, N.N., D’Souza, B.B., Geracioti Jr., T.D., 2004. Pituitary-thyroid state correlates with central dopaminergic and serotonergic activity in healthy humans. Neuropsychobiology 49, 84-87.

Susser, E.S., Lin, S.P., 1992. Schizophrenia after prenatal exposure to the Dutch Hunger Winter of 1944-1945. Arch. Gen. Psychiatry 49, 983-988.

Suzuki, N., Oh-Nishi, A., Saji, M., 2004. Dopamine D2-like receptor function is reverted by thyroid hormone in early developmental hippocampus. Program No. 277.10. Abstract Viewer/Itinerary Planner. Society for Neuroscience, Washington, DC. Online.

Taimi, M., Helvig, C., Wisniewski, J., Ramshaw, H., White, J., Amad, M., Korczak, B., Petkovich, M., 2004. A novel human cytochrome P450, CYP26C1, involved in metabolism of 9-cis and all-trans isomers of retinoic acid. J. Biol. Chem. 279, 77-85.
Tsuang, M.T., Stone, W.S., Faraone, S.V., 2001. Genes, environment and schizophrenia. Br. J. Psychiatry 40, s18-s24.

Venken, T., Claes, S., Sluijs, S., Paterson, A.D., van Duijn, C., Adolfsson, R., Del-Favero, J., Van Broeckhoven, C., 2005. Genomewide scan for affective disorder susceptibility loci in families of a northern Swedish isolated population. Am. J. Hum. Genet. 76, 237-248.

Vermot, J., Pourquie, O., 2005. Retinoic acid coordinates somitogenesis and left-right patterning in vertebrate embryos. Nature $435,215-220$.

Vermot, J., Gallego Llamas, J., Fraulob, V., Niederreither, K., Chambon, P., Dolle, P., 2005. Retinoic acid controls the bilateral symmetry of somite formation in the mouse embryo. Science 308, 563-566.

Villa, A., Santiago, J., Belandia, B., Pascual, A., 2004. A response unit in the first exon of the beta-amyloid precursor protein gene containing thyroid hormone receptor and Sp1 binding sites mediates negative regulation by 3,5,3'-triiodothyronine. Mol. Endocrinol. 18, 863-873.

Wallen-Mackenzie, A., Mata de Urquiza, A., Petersson, S., Rodriguez, F.J., Friling, S., Wagner, J., Ordentlich, P., Lengqvist, J., Heyman, R.A., Arenas, E., Perlmann, T., 2003. Nurr1-RXR heterodimers mediate RXR ligand-induced signaling in neuronal cells. Genes Dev. 17, 3036-3047.

Weitzel, J.M., Iwen, K.A., Seitz, H.J., 2003. Regulation of mitochondrial biogenesis by thyroid hormone. Exp. Physiol. 88, 121-128.

Werme, M., Ringholm, A., Olson, L., Brene, S., 2000. Differential patterns of induction of NGFI-B, Nor1 and c-fos mRNAs in striatal subregions by haloperidol and clozapine. Brain Res. 863, 112-119.

Weston, A.D., Blumberg, B., Underhill, T.M., 2003. Active repression by unliganded retinoid receptors in development: less is sometimes more. J. Cell Biol. 161, 223-228.

Wietrzych, M., Meziane, H., Sutter, A., Ghyselinck, N., Chapman, P. F., Chambon, P., Krezel, W., 2005. Working memory deficits in retinoid X receptor gamma-deficient mice. Learn. Mem. 12, 318-326.

Wijsman, E.M., Rosenthal, E.A., Hall, D., Blundell, M.L., Sobin, C., Heath, S.C., Williams, R., Brownstein, M.J., Gogos, J.A., Karayiorgou, M., 2003. Genome-wide scan in a large complex pedigree with predominantly male schizophrenics from the island of Kosrae: evidence for linkage to chromosome 2q. Mol Psychiatry 8, 695-705.

Wolf, G., 2002. The regulation of the thyroid-stimulating hormone of the anterior pituitary gland by thyroid hormone and by 9-cisretinoic acid. Nutr. Rev. 60, 374-377.

Yamamoto, M., Drager, U.C., Ong, D.E., McCaffery, P., 1998. Retinoid-binding proteins in the cerebellum and choroid plexus and their relationship to regionalized retinoic acid synthesis and degradation. Eur. J. Biochem. 257, 344-350.

Yang, Y.F., Qin, W., Shugart, Y.Y., He, G., Liu, X.M., Zhou, J., Zhao, X. Z., Chen, Q., La, Y.J., Xu, Y.F., Li, X.W., Gu, N.F., Feng, G.Y., Song, H., Wang, P., He, L., 2005. Possible association of the MAG locus with schizophrenia in a Chinese Han cohort of family trios. Schizophr. Res. 75, 11-19.

Ye, Q., Shieh, J.H., Morrone, G., Moore, M.A., 2004. Expression of constitutively active Notch4 (Int-3) modulates myeloid proliferation and differentiation and promotes expansion of hematopoietic progenitors. Leukemia 18, 777-787.

Yen, P.M., 2001. Physiological and molecular basis of thyroid hormone action. Physiol. Rev. 81, 1097-1142.

Zetterström, R.H., Solomin, L., Jansson, L., Hoffer, B.J., Olson, L., Perlmann, T., 1997. Dopamine neuron agenesis in Nurr1deficient mice. Science 276, 248-250.

Zoeller, R.T., Rovet, J., 2004. Timing of thyroid hormone action in the developing brain: clinical observations and experimental findings. J. Neuroendocrinol. 16, 809-818. 